\title{
Flow Stagnation under Single and Two-Phase Natural Circulation Conditions in the APEX-CE Test Facility
}

\author{
José N. Reyes Jr. \\ Department of Nuclear Engineering, The College of Engineering, Radiation Center, Oregon State University, \\ Corvallis, OR 97331-4501, USA \\ Correspondence should be addressed to José N. Reyes Jr., jose.reyes@oregonstate.edu
}

Received 30 May 2007; Accepted 29 February 2008

Recommended by John Cleveland

Natural circulation experiments were conducted at Oregon State University using the advanced plant experiment (APEX-CE) integral system test facility as configured to simulate a typical $2 \times 4$ Combustion Engineering nuclear steam supply system. This paper describes the mechanisms by which natural circulation flow was interrupted under single-phase and two-phase natural circulation conditions in APEX-CE.

Copyright (C) 2008 José N. Reyes Jr.. This is an open access article distributed under the Creative Commons Attribution License, which permits unrestricted use, distribution, and reproduction in any medium, provided the original work is properly cited.

\section{INTRODUCTION}

Natural circulation is an important means of cooling the nuclear core in the event of a loss of primary system pumps. This paper describes the mechanisms that can interrupt natural circulation in loops transporting single- and twophase fluids. The investigation of these mechanisms was conducted in the APEX-CE test facility, at Oregon State University [1-7]. A schematic of the test facility is shown in Figure 1. APEX-CE was configured to model a $2 \times 4$ loop Combustion Engineering PWR. It included the reactor vessel with an electrically heated rod bundle, a pressurizer, two inverted U-tube steam generators, four cold legs and reactor coolant pumps, two hot legs, and a safety injection system. The facility had a length scale ratio of approximately $1: 4$ and a volume ratio of $1: 274$. It was operated at decay powers ranging down from $6 \%$. Therefore, the tests were conducted after reactor scram with the reactor coolant pumps tripped in a natural circulation mode of operation.

The motivation for the studies in APEX-CE was an issue known as pressurized thermal shock (PTS). In the event of an emergency that results in a significant loss in system pressure or fluid inventory, cold borated water is typically injected into the primary system via the cold legs. If the flow rate in the primary loop is significant, the cold injected fluid will thoroughly mix with the hot water in the primary loop. However, at very low flow rates, the cold injected fluid will stratify in the loops and form cold plumes in the downcomer. Should a pre-existing flaw in the vessel wall or welds exist at a location experiencing prolonged contact with a cold plume, while at high pressure, there is a potential for the flaw to grow into a "through-wall" crack. Sections 2 and 3 describe mechanisms leading to a loss of primary loop flow.

\section{SINGLE-PHASE NATURAL CIRCULATION STAGNATION MECHANISMS}

This section describes the mechanisms that interrupt singlephase natural circulation. Figure 2 presents a simple sketch describing the single-phase fluid natural circulation flow paths. Each loop in the Nuclear Steam Supply System shown in Figure 2 contains a hot leg, a steam generator, a loop seal (i.e., a cross-over leg), a pump, and a cold leg. The flow areas will vary around the loop. Under certain conditions, involving a reactor scram, the reactor coolant pumps in the plant may trip causing a coast down in the loop flow. Subsequent to a reactor scram, reactor decay power continues to heat the fluid in the vessel, while the steam generators continue removing heat at an elevation well above the core. The density difference and elevation difference produce a buoyancy force that drives the fluid around the loop. This buoyancy driven flow is known as natural circulation. The natural circulation flow rate is limited by the friction and form losses in the loop piping and components. 


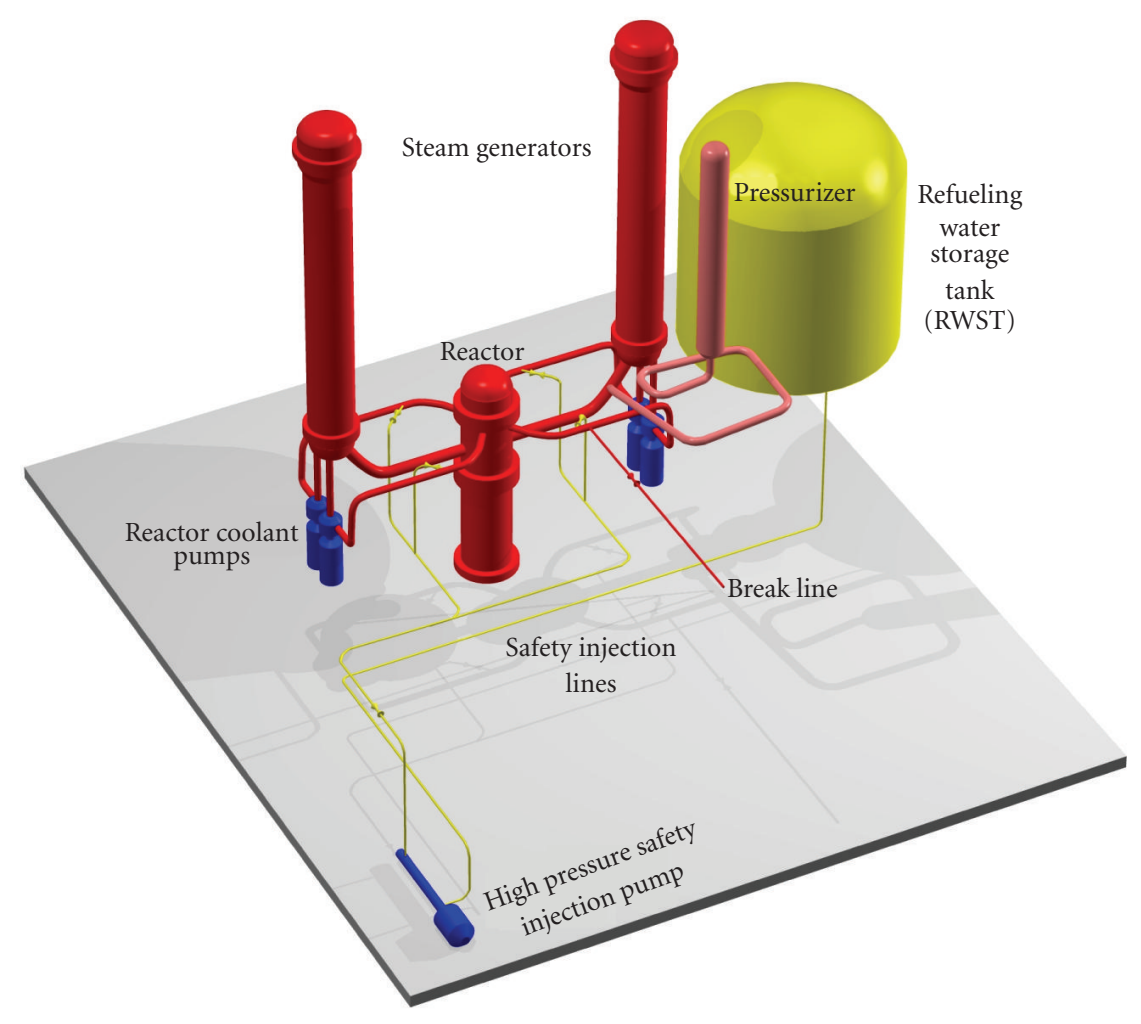

FIgUre 1: Schematic of the APEX-CE test facility.

The dominant pressure drops in the loop occur in the core and in the steam generator as a result of form losses, usually expressed in terms of loss coefficients, K. As shown Figure 2, the primary loop is divided into: a hot fluid side having an average temperature $T_{H}$ and a cold fluid side having an average temperature $T_{C}$.

\subsection{Loss of heat sink (steam generator reverse heat transfer)}

One mechanism for losing single-phase natural circulation flow is a loss of heat sink. This can occur as a result of a loss of main and auxiliary feedwater supplies. This could also occur as a result of a main steam line break (MSLB) in a single steam generator in a multiloop plant. In the event of a MSLB, the operators isolate the feedwater to the steam generators and close the main steam isolation valves. The affected steam generator, however, will continue to vent steam and depressurize. The blowdown of a steam generator may result in a rapid cooling of the primary system fluid. As a result, the primary loop fluid temperatures may drop below the secondary side temperatures of the "unaffected" steam generators. The result is a loss of heat sink in the loops not experiencing the steam line break. Figure 3 shows that stagnation occurs in cold legs no.1 and no.3, connected to the unaffected Steam Generator no. 1 for this test. Figure 4 shows the flow rates for cold leg no.1 and no.3. When primary side temperature exceeds the secondary side temperature, natural circulation flow is restored.

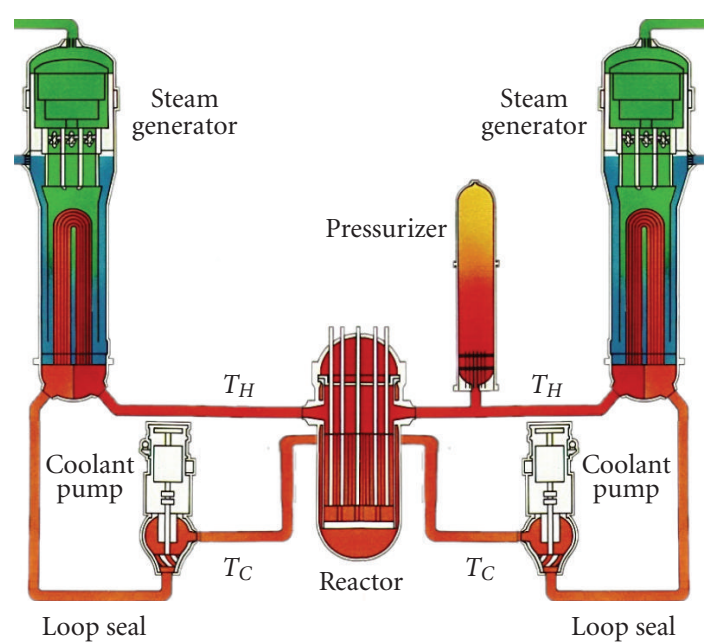

FIGURE 2: Control volume for single-phase natural circulation in a two-loop PWR.

\subsection{Negatively buoyant regions in loop (loop seal cooling)}

Another mechanism that can interrupt single-phase natural circulation flow is loop seal cooling. The piping that connects the steam generator lower channel head to the reactor coolant pump is known as the cross-over leg or the reactor pump loop seal as shown in Figure 2. Overcooling transients 


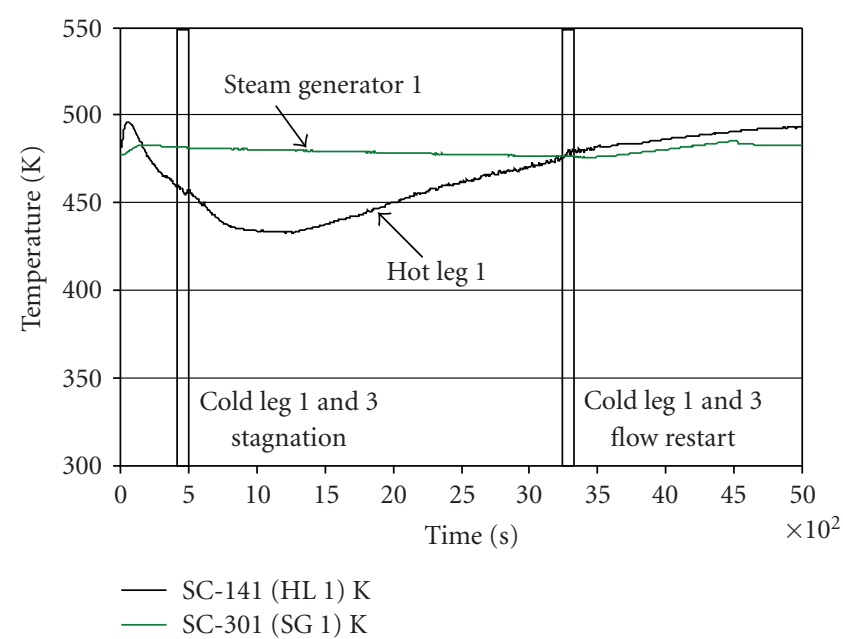

FIgURE 3: Illustration of steam generator reverse heat transfer during a main steam line break simulation and recovery (OSU-CE0012).

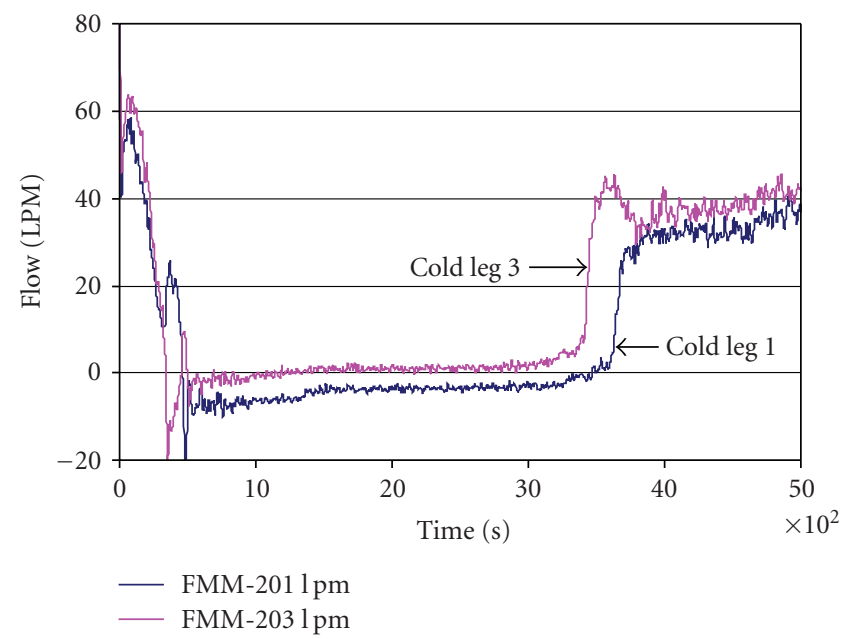

FIgURE 4: Illustration of loss of natural circulation flow during a main steam line break simulation and recovery (OSU-CE-0012).

such as main steam line breaks, result in a primary side cooldown. If the primary side pressure drops below the safety injection actuation setpoint, cold-borated water will be injected into the loop. This water is typically injected into the cold legs of a PWR between the reactor coolant pump and the reactor vessel. Figure 5 is a picture of the transparent separate effects test loop at Oregon State University used to visualize fluid mixing in a side-injection cold leg.

The dense injected fluid simulated, using fluorescent saltwater, falls to the bottom of the cold leg where it spreads out toward the vessel and the reactor coolant pump loop seal. Countercurrent flow is established with hot water at the top of the cold leg pipe flowing toward the injection point. The dense-injected water mixes with the less dense water in the loop seal creating a negatively buoyant region in the loop, effectively increasing the resistance to flow in that loop. For multiloop plants, the flow is preferentially diverted

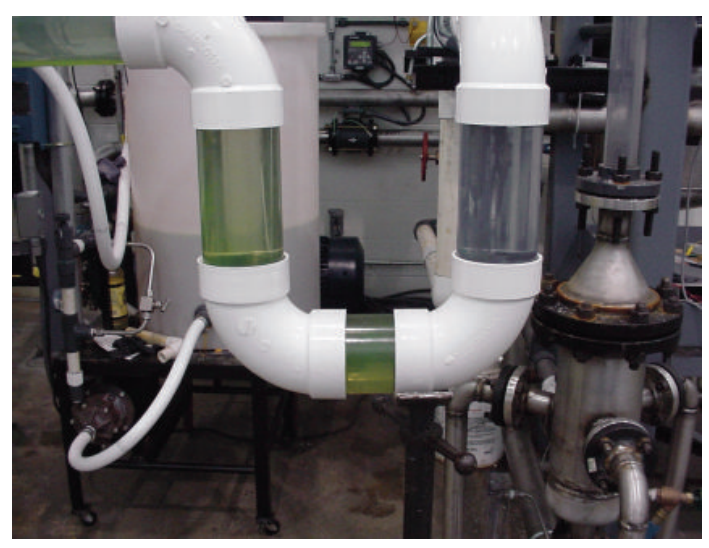

FIGURE 5: Flow visualization of injected coolant mixing with fluid in a transparent loop seal.

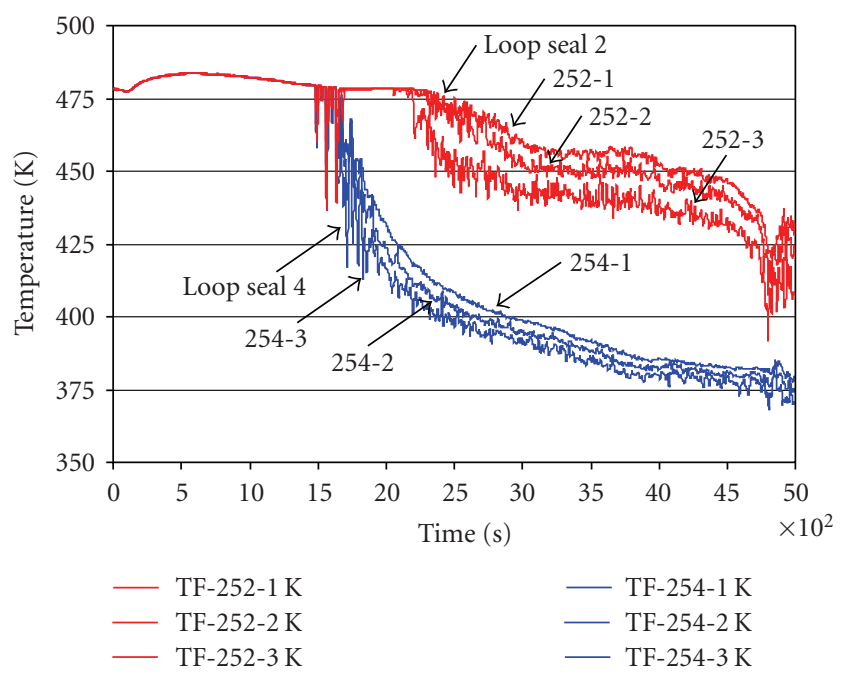

Figure 6: Asymmetric loop seal cooling (OSU-CE-0008).

to the adjacent cold leg through the SG lower provided the same condition does not also exist there. Figure 6 shows the asymmetric cooling of two loop seals attached to a single steam generator in APEX-CE. Loop seal no.4 cools faster than loop seal no. 2 because the dense fluid back flows over the lip of RCP no.4 earlier during this particular transient. Figure 7 shows that loop flow in cold leg no.4 stagnates earlier than the flow in cold leg no.2.

\section{TWO-PHASE NATURAL CIRCULATION STAGNATION MECHANISMS}

During a small break loss of coolant accident (SBLOCA) in a PWR, steam generator tube draining will result in a gradual decrease in primary side natural circulation flow until it transitions to a boiling-condensing mode of operation. Figure 8 shows the results of a test conducted at OSU to investigate this phenomenon. The test, OSU-CE-0002, was a stepped reduction in inventory test. In essence, it is a quasisteady SBLOCA. It was conducted at a constant core 


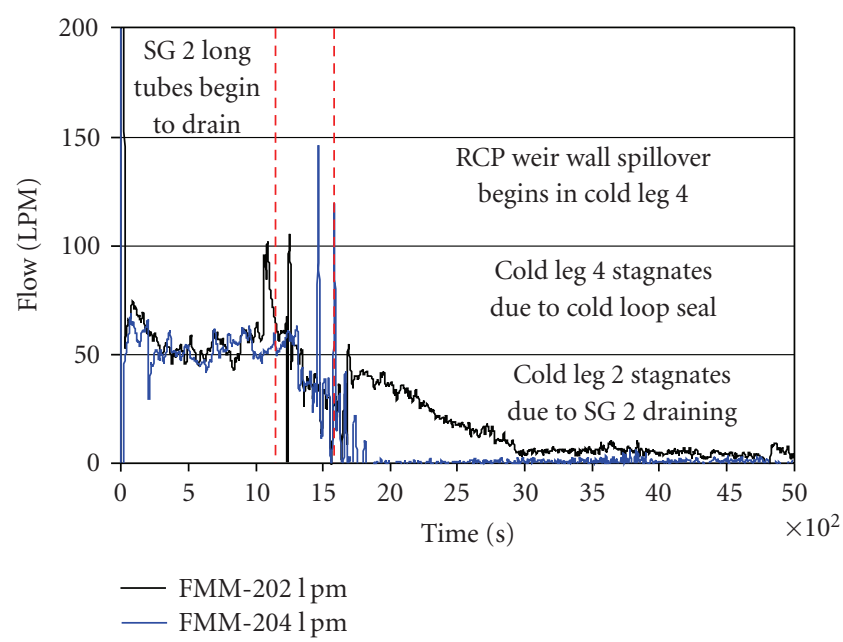

FIgURE 7: Stagnation of a primary loop due to loop seal cooling (OSU-CE-0008).

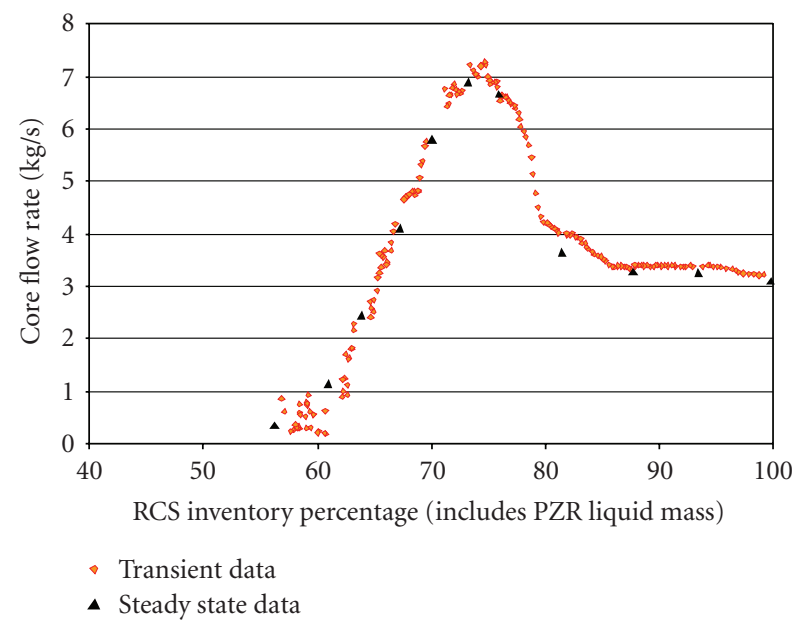

FIGURE 8: Cold leg flow rates as a function of primary side inventory during a stepped-inventory reduction test (OSU-CE-0002).

power of $275 \mathrm{~kW}$ and initiated from steady-state single-phase natural circulation conditions. A break valve on the reactor vessel was opened to remove primary fluid in stepped intervals. After a short period, the break valve was closed and the loop was allowed to reach a new quasisteady state flow rate. The cold leg flow rates were measured at each interval. These tests were similar to tests performed at the Semiscale test facility at the Idaho National Engineering Laboratory as shown in Figure 9 [6].

As liquid mass is removed from the system, the loop void fraction increases. This resulted in a rise in the loop flow rates above those observed for single-phase natural circulation as shown in Figure 8. At approximately $70 \%$ inventory in APEX-CE, the flow reaches a maximum value. This corresponds to the maximum two-phase buoyancy driving head for the test. Eventually, the steam generator tubes begin to drain causing a decrease in flow rate because the distance between the core and steam generator thermal

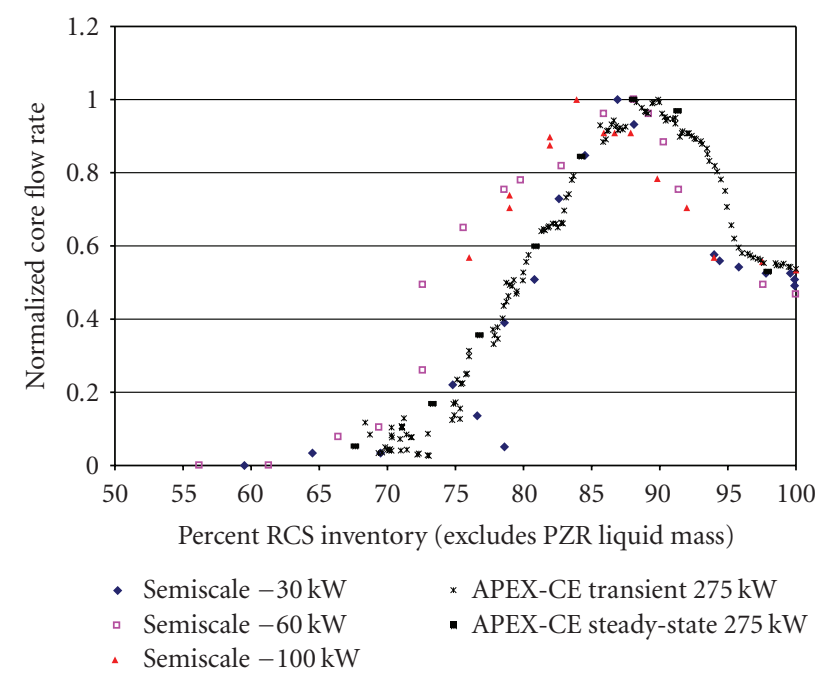

FIGURE 9: Cold leg flow rates as a function of primary side inventory during a stepped-inventory reduction test (OSU-CE-0002) and semiscale Mod 2A data [6].

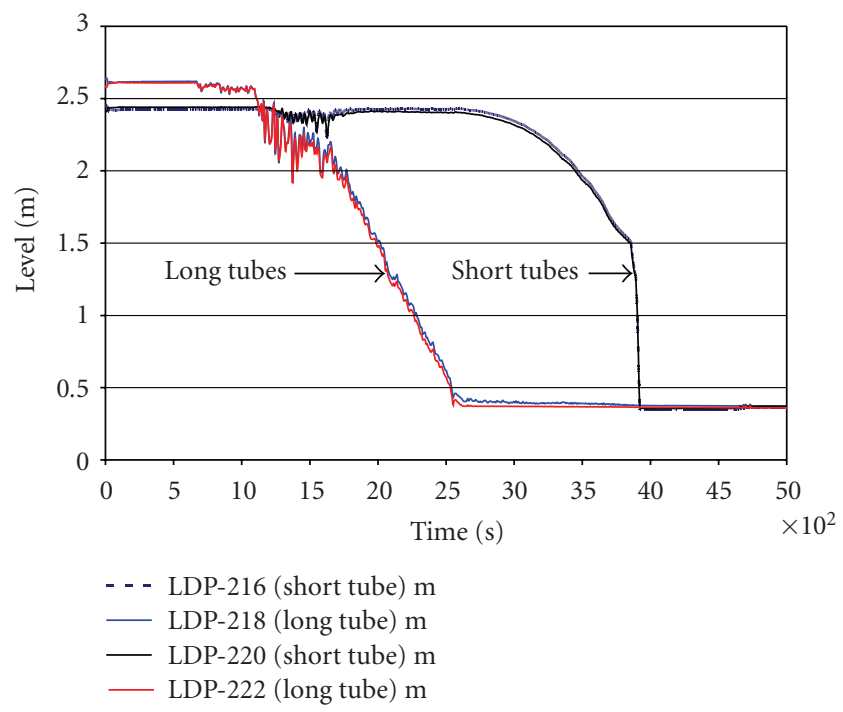

FIGURE 10: Liquid levels in the longest and shortest tubes of steam generator no.2 during SLOCA test (OSU-CE-0008).

centers has decreased and interruption of flow in the longest tubes.

Figure 10 illustrates the significant difference in draining time for the longest U-tubes at the top of the bundle and the shortest U-tubes at the bottom of the bundle. The long tubes drained much earlier than short tubes. However, some primary loop natural circulation continued until the short tubes drained. These results suggest that to obtain faithful simulations of the steam generator tube draining requires modeling multiple steam generator tubes. 


\section{CONCLUSIONS}

Experiments in the APEX-CE integral system test facility indicate that natural circulation under single-phase fluid condition can be interrupted as a result of a loss of heat sink during a main steam line break (i.e., reverse steam generator heat transfer), or as the result of the formation of negatively buoyant conditions in the loop seal. Under two-phase natural circulation conditions, loop stagnation arises as a result of steam generator tube voiding. The loop flow transitions from two-phase natural circulation to a boiling-condensing mode of operation. The APEX-CE tests indicate that the long steam generator tubes drain before the short tubes suggesting that computer code models include multiple steam generator tubes. The formation of negatively buoyant conditions in plants with loop seals can also result in asymmetric loop stagnation under two-phase natural circulation flow conditions.

\section{ACKNOWLEDGMENT}

This test program was supported by the U.S. Nuclear Regulatory Commission as part of its review of the technical basis for revision of the pressurized thermal shock (PTS) screening criterion in the PTS rule (10 CFR 50.61).

\section{REFERENCES}

[1] J. N. Reyes Jr., "Scaling analysis for the OSU APEX-CE integral test facility," Oregon State University, NUREG/CR-6731, ADAMS No. ML043570429, 2004.

[2] J. N. Reyes Jr., et al., "Final report for the OSU APEX-CE integral test facility," Oregon State University, NUREG/CR6856, ADAMS No. ML043570405, 2004.

[3] J. N. Reyes Jr., J. T. Groome, A. Y. Lafi, D. Wachs, and C. Ellis, "PTS thermal hydraulic testing in the OSU APEX facility," International Journal of Pressure Vessels and Piping, vol. 78, no. 2-3, pp. 185-196, 2001.

[4] K. Abel, E. P. Young, and J. N. Reyes Jr., "Summary of MSLB tests OSU-CE-0011 and OSU-CE-0012," in Proceedings of the American Nuclear Society Winter Meeting (ANS '01), Reno, Nev, USA, November 2001.

[5] J. N. Reyes Jr., K. Welter, and S. Antoine, "Primary loop stagnation related to PTS in SBLOCA experiments at APEXCE," in Proceedings of the American Nuclear Society Winter Meeting (ANS '01), Reno, Nev, USA, November 2001.

[6] A. Y. Lafi and J. N. Reyes Jr., "RELAP5 calculations of a natural circulation stepped inventory reduction test," in Proceedings of the American Nuclear Society Winter Meeting (ANS '01), Reno, Nev, USA, November 2001.

[7] A. Y. Lafi and J. N. Reyes Jr., "RELAP5 analyses for the simulated $0.09 \mathrm{~m}^{2}$ APEX-CE MSLB," in Proceedings of the American Nuclear Society Winter Meeting (ANS '01), Reno, Nev, USA, November 2001. 

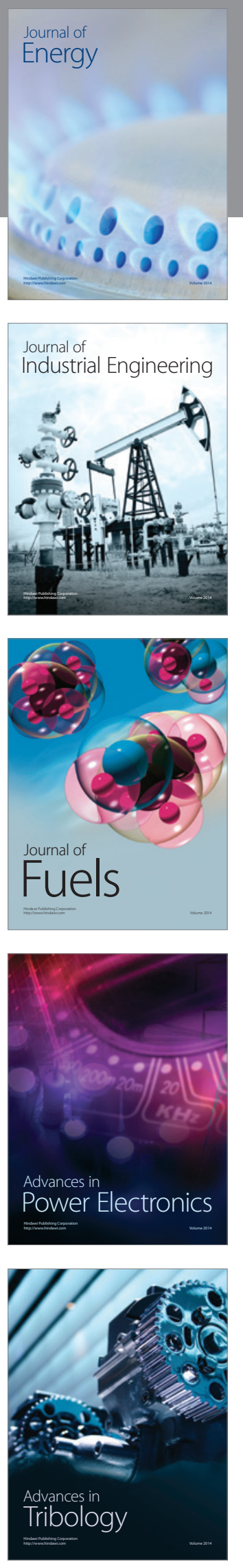
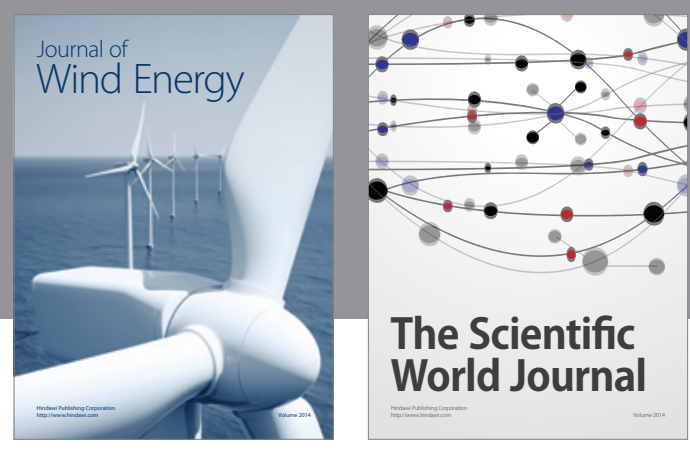

The Scientific World Journal

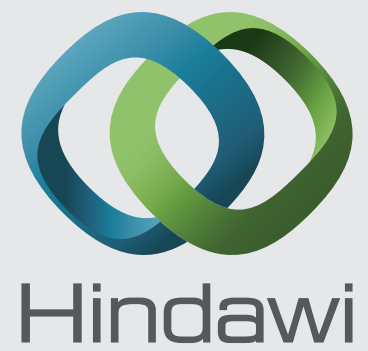

Submit your manuscripts at http://www.hindawi.com
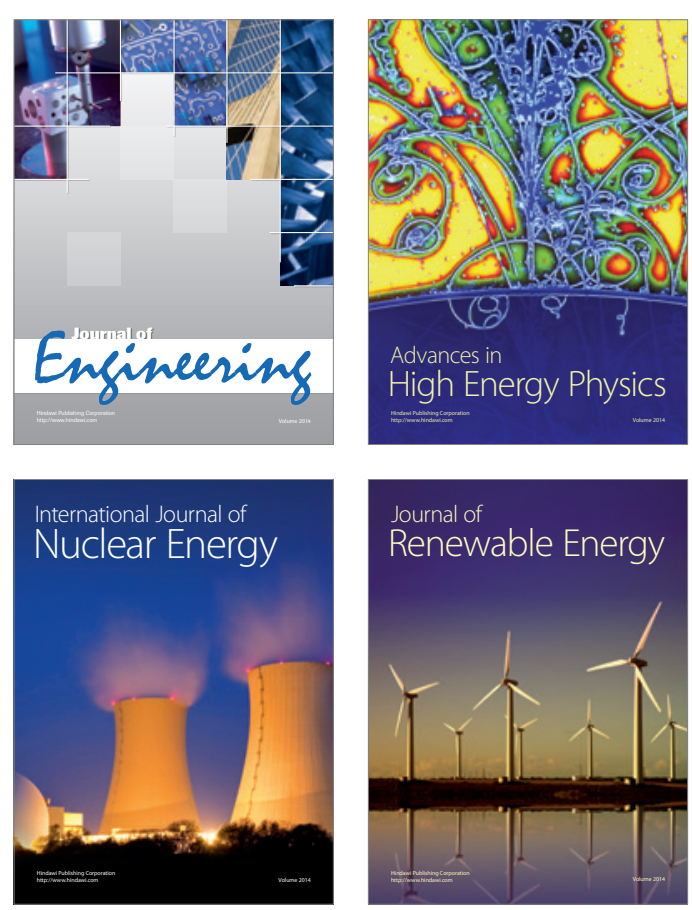

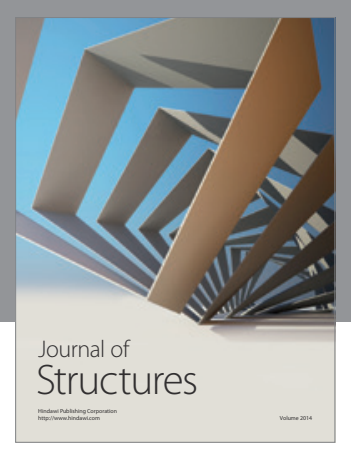

Rotating
Mechinery
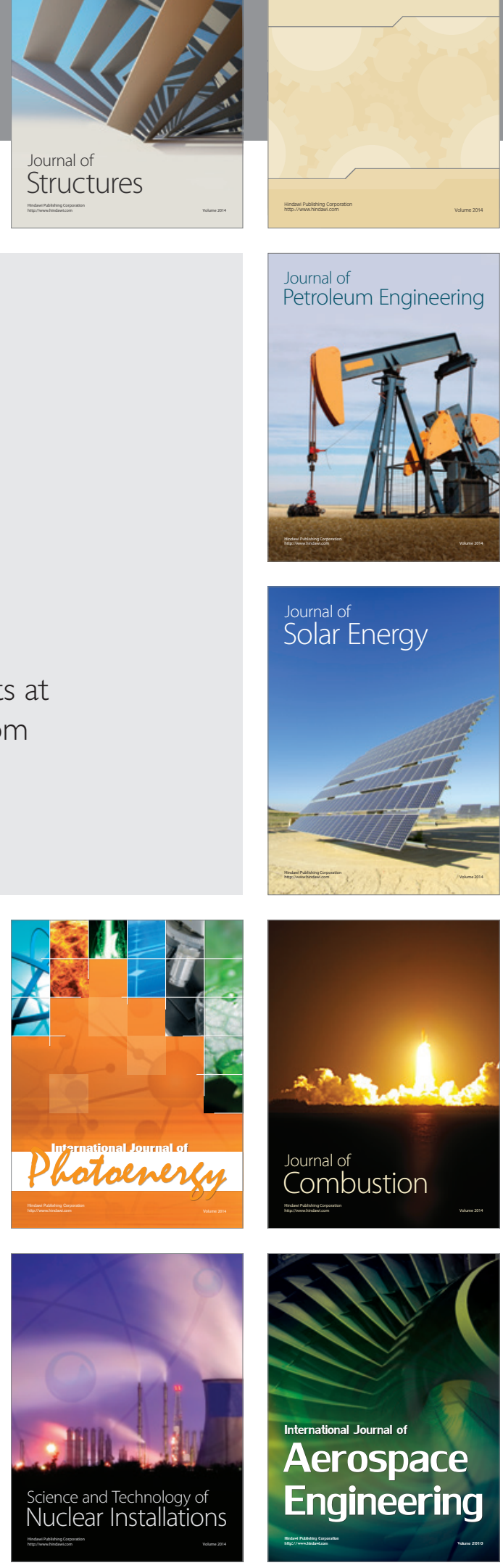